\title{
Understanding the Meanings and Factors Motivating Academic Fraud: Exploration in Accounting Students
}

\section{Sukma Dephiena ${ }^{1}$ \\ Fakultas Ekonomi dan Bisnis \\ Universitas Airlangga, Indonesia}

\begin{abstract}
Surel: dephiena@yahoo.com
ABSTRACT

The purpose of this research is to depict the understanding of academic fraud and to elaborate the motivation to the perpetrators. This research uses qualitative approach with doing phenomenology variation of qualitative research with interview and literature documentation as the data collection method. The result of this research reveals the academic fraud conducted by the accounting student in breaking the rules, the existence of fraud culture that make student doing the academic fraud, and the ambition that motivate students to do fraud. Therefore, ambition as the motivation factor which underlined the academic fraud can be reduced by increasing the supervising more than usual. In line with the result of research that hopefully can be more contribute in to academic institution for make a better methods to decreasing the number of cheater.
\end{abstract}

Keywords: Academic Fraud; Student Ethics; Fraud Definition; Fraud Motivation.

\section{Memahami Makna dan Faktor yang Memotivasi Penipuan Akademik: Eksplorasi pada Mahasiswa Akuntansi}

\begin{abstract}
ABSTRAK
Tujuan dari penelitian ini adalah untuk mendeskripsikan pemahaman tentang kecurangan akademik dan untuk mengetahui motivasi para pelakunya. Penelitian ini menggunakan pendekatan kualitatif dengan melakukan penelitian kualitatif variasi fenomenologi dengan wawancara dan dokumentasi pustaka sebagai metode pengumpulan datanya. Hasil penelitian menunjukkan adanya kecurangan akademik yang dilakukan oleh mahasiswa akuntansi dalam melanggar aturan, adanya budaya kecurangan yang membuat mahasiswa melakukan kecurangan akademik, dan ambisi yang memotivasi mahasiswa untuk melakukan kecurangan. Oleh karena itu, ambisi sebagai faktor motivasi yang menggarisbawahi kecurangan akademik dapat dikurangi dengan meningkatkan pengawasan lebih dari biasanya. Sejalan dengan hasil penelitian yang diharapkan dapat lebih berkontribusi pada institusi akademik untuk membuat metode yang lebih baik untuk mengurangi jumlah penipu.
\end{abstract}

Kata Kunci: Kecurangan Akademik; Etika Mahasiswa; Definisi Penipuan; Motivasi Penipuan.

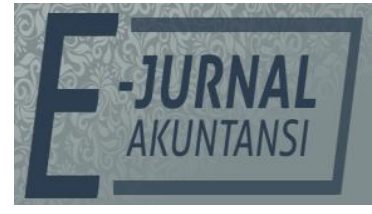

e-ISSN 2302-8556

Vol. 30 No. 9

Denpasar, September 2020

Hal. 2257-2269

DOI:

10.24843/EJA.2020.v30.i09.p07

PENGUTIPAN:

Dephiena, S. (2020).

Understanding the Meanings and Factors Motivating Academic Fraud:

Exploration in Accounting Students. E-Jurnal Akuntansi, 30(9), 2257-2269

RIWAYAT ARTIKEL:

Artikel Masuk: 5 April 2020 Artikel Diterima: 26 Agustus 2020

Artikel dapat diakses : https://ojs.unud.ac.id/index.php/Akuntansi/index 


\section{INTRODUCTION}

Ethical problem which happens in education become a phenomenon that is being questioned for the professionalism and the students ethical behavior. This fact was proved in the fraud that happened in the world's famous institution, Harvard University, revealing about 125 students conducting the fraud in their final take-home exams (Mavisakalyan \& Meinecke, 2016). As an Accountant we have to understand about what is the liability and risks of the profession, in a way with understanding of liability and risks is being skeptic to get the detail and carefull about the finance things Kartikasari et al., (2017), so then we have to pay attention on the accounting study when it on college, accounting major has the opportunity to has a professional carrer and the fraudulent is stick on the accountant profession. The reason of accounting profession can do the fradulent behavior because of the have the opportunity to make the organization standard and being the auditor that can checking the financial information (Mavisakalyan \& Meinecke, 2016).

The next professional have to not ignore fraudulent possibility, it can be detected while accounting students are still learning in college as known academic fraudulent. According to the Law of the Republic of Indonesia 2012 academic fraudulent is such a unethical behavior related to student's abuses, cheating can be committed by anyone, despite the degree of academic dishonesty based on gender, college origin and level of study. That is why college has an important role in creating high qualifying graduate, because of it, Indonesian governments giving recognition in the form of accreditation education standard by educational institution authorized by the government. This recognition of accreditation must be owned by every college institution whether it is public universities (PTN) or private universities (PTS). Which means that every type of university has tendency to do an academic fraud, for instance, one of the best state university in Indonesia has admitted that the students are doing the academic cheating.

Besides of the academic fraudulent cases, the university cannot avoid their rules for the college students. Based on the accreditation appraisal done by Badan Akreditasi Nasional Perguruan Tinggi (BAN-PT) stated that the quality of graduates is an appraisal for the accreditation of study programs. Therefore, every study program on the college institution must guarantee the quality of its graduates, so that the study program decide the graduate conditions such as minimum score. Similarly, a graduation requirement applied by Faculty of Economics and Business Universitas Brawijaya which has 2,75/4,00 as the minimum of Grade Point Average (IPK). The example to reach the perfect score, students doing the "cheating contract" it means students has pay other people to making out their assignment to finish it, so then, teacher or instructor have to pay attention on the risk of cheating to make the best professional.

Otherwise, the purpose of this study is for giving a vision about the fraud that is done by undergraduate accounting students by giving the understanding about the academic fraud according to accounting students and knowing the motivation that the perpetrators of fraud have. This research will be held on state university at Malang and private university in Surabaya who are still active in the odd semester 2018/2019 to find out the reason of student's academic fraud and the motivation of student's academic fraud. This study might be contribute 
based on theory, practice, and academics it is because of the theory of academic fraud is describing the quality of accountant successor. Contribute in practice it means that each university can improving their policy to decreasing the number of cheater, then to contribute as an academics is expected to provide the information of student's motivations and the understanding of the effecting to their future.

\section{RESEARCH METHOD}

Qualitative research can evaluate the daily lives of humans, but the research will be discussed in an environment that will be examined. Because researchers are required to consider about the possibilities and potentials of what can influence research or problems that can change the state of the object of research (Yin, 2011). Therefore, research in qualitative form will be examined because there is a phenomenon that occurs in the community and is given specifically, which can explain how the phenomenon occurs and whether there might be a solution (Moleong, 2015). This research using phenomenological approach to make sure that the data validation are believable using interview and literature documentation as the data collecton method.

Qualitative research is a data collection method that relies on the emergence of a phenomenon that attracts the attention of researchers (Moleong, 2015). This method also aims to understand the phenomenon experienced by the research subject such as behavior, perception, motivation, action, etc. holistically and in descriptive way in the form or words and language, in the natural special context using some scientific methods (Moleong, 2015). This research uses primary data as the data source. Primary data is relevant data which means that the data that is obtained based on the observation or interview, it is not secondary data that is obtained from other researchers (Yin, 2011).

The Data is taken in state university in Malang and Private University in Surabaya, researcher using different city to make sure that the probability of different behavior are appeared in a good way. As same as the reason of choosing different city, using sample from state university and private university is also because of the policy are quietly different. The state university are choosen because of they are has a ranked between $1^{\text {st }}$ to $10^{\text {th }}$ based on nationality rank and the private university has the good score in the private university in Surabaya. Therefore those universities are the right choice because of both universities placed in the same province but still have different culture and also different policy for cracking down the student's fraudulent.

This research uses primary data as the data source. Primary data is relevant data which means that the data that is obtained based on the observation or interview, it is not secondary data that is obtained from other researchers (Moleong, 2015). Researcher has the informant that is considered as an honest-trustworthy also it has been confirmed that surely know the fraud itself which are active students of accounting department in State University and Private University, that have GPA $>3.0$ also have been taking Introduction of Accounting I course, Business Ethics, and Audit. Those courses are choosen because it will effect directly on the kind of jobs, such as company's accountant or an auditor. So that the students as the informants that will participate in this 
research ask for anonymity, it is because the confession in this academic fraud is very sensitive thing for further disclosed.

Table 1. Table of Informant

\begin{tabular}{|c|c|c|c|}
\hline No. & Name & Details & Grade \\
\hline 1. & *Tapasya & $\begin{array}{l}\text { Student in Accounting Department Private } \\
\text { University Class of } 2017\end{array}$ & 3,12 \\
\hline 2. & ${ }^{*}$ Cimut & $\begin{array}{l}\text { Student in Accounting Department Private } \\
\text { University Class of } 2017\end{array}$ & 3,24 \\
\hline 3. & *Ucet & $\begin{array}{l}\text { Student in Accounting Department Private } \\
\text { University Class of } 2017\end{array}$ & 3,83 \\
\hline 4. & *Ronaldo & $\begin{array}{l}\text { Student in Accounting Department State } \\
\text { University Class of } 2017\end{array}$ & 3,92 \\
\hline 5. & *Putri & $\begin{array}{l}\text { Student in Accounting Department State } \\
\text { University Class of } 2017\end{array}$ & 3,46 \\
\hline 6. & ${ }^{*}$ Nur & $\begin{array}{l}\text { Student in Accounting Department State } \\
\text { University Class of } 2017\end{array}$ & 3,39 \\
\hline
\end{tabular}

Source: Research Data, 2019

The first data analysis technique is a reduction, in this case researcher identified the collected data that has been taken to be redacted, and so can be one unit. Category in this research has been sorted by the topic that researcher take, that are divided based on research question, such as informant's answer will be categorized based on the one sub-chapter. In this research, there are two units that are understanding the academic fraud and motivation of doing fraud. This reduction can be used for the party that can be linked to the focus and problem of the research, so it makes that small part has meanings (Moleong, 2015). Categorization is the second technique after the reduction, it is the sorting part between units that have been made in the reduction phase (Moleong, 2015). The last process, that is synthesis, it is the way when researcher find the linked between one unit to another unit (Moleong, 2015). The next stage the researcher makes coding, which means that each unit of data collected by the researcher is given a code to differentiate each unit to make it easier to trace (Moleong, 2015). In this reduction stage the researcher can review and reflect on the data that has been collected, also depending on the degree of type of data collected and the method of recording data.

\section{RESULTS AND DISCUSSION}

Academic fraud is a threat to the intellectual integrity on which the advancement of knowledge depends (Minerva, 1986). The academic dishonesty is the intentional participation deceptive practices regarding one's academic work or the work of another (Faucher \& Caves, 2009).

This research is really important because students who did the academic frauds in college will makes a professionals that has less ethical attitude in their own job in the future (Teixeira \& Rocha, 2010). Fraud is an act that used illegally ways to get the success in academically or avoiding the academic failure (Nursalam et al., 2013). As for academic fraud technique such as giving, receiving, or receiving information from other people, using materials or forbidden information, and ignoring the scoring process (Faucher \& Caves, 2009). From those explanations, it can be concluded that fraud is a rule violation that have been done by fraud perpetrators. 
"The definition of fraud based on my opinion is negative things which intentionally done to break the existing rules (exam's rule)."

The wide influence of academic fraud is hard to be measured and it has little expectation, but in some well-known universities, this thing is easy to be detected (Epstein, 1986). There was awareness in the students toward the punishment that will be accepted for the students was the main purpose of an educational institution in an exam's rule, but the awareness of the students did not reduce the students' intentions in doing academic fraud.

"Academic fraud is a breaking rule-activity and it should not be done. But because there are some factors so this thing becomes okay based on my opinion."

The factors that underlined the students in doing fraud were there was a difficulty in doing the task, needing the real answer, there was an influence from other students, less time available, students did not understand the topic, there was no punishment if they were caught in doing frauds, getting good scores (Nursalam et al., 2013). However on this research, the researcher did not only find those factors above, but there was a solidarity toward friends who could not do the task, it was also the factor that could be considered.

"Fraud in the class cannot be done, but if there is someone needs and they totally cannot do the task, automatically, me as a friend will give my answer."

Academic frauds that had been done by students were actually either realized and not realized if they did were actually frauds that may be subject to punish (Sagoro, 2013). Meanwhile that happened on the informant was there was an awareness with the sanction that will be accepted, but they made this thing became something that was allowed by the rules. In this case as a faculty party, Dr. Dedhy Sulistiawan, M.Sc. as the head of the accounting program in University of Surabaya stated that code of conduct in the examination had been explained on the orientation period so it did not need to be explained anymore and it was expected for every students to understand the code of conduct, the punishment that had been mentioned was clear and there were many clear evidences, such as student's course that had been cut off along one semester from the student who did fraud in the examination time. Therefore, the application of the sanction also had been explained by the faculty openly and the threat were always haunting the students in order to reduce the academic fraud.

Fraud is the beginning of academic integrity violation, which means that it has taken an advantage from the result by the student who has the responsibility and desire toward the wrong knowledge (King et al., 2009). While according to researcher based on the result from the informants, this stated that academic fraud had become negative act that considered as reasonable act because there was an encouragement and intention in breaking the rules and a chance which triggered the academic fraud, also relied to the system of weak examination supervisor.

Culture can be defined as the accumulation of meaning from together, ritual, norm, and tradition which distinguish from one to another community (Yeganeh, 2914). As the research done by Teixeira \& Rocha (2010) stated that $80 \%$ from their correspondent stated that fraud was a normal thing to do, they had seen their colleagues did copying and half of them stated that some of their colleagues had been caught by doing copying. In this research, the researcher 
found the definition which was caused by bad culture on the students. This culture had been realized by some informants which stated:

"Based on my opinion, fraud is natural human thing, every person have been did the fraud. At least, if they were school kid, they must had cheating. But all of that indeed, it is encouraged from intention and chance that owned by every person."

Fraud act was based on the intention and habit that was owned by every person, so the academic fraud had become a normal thing in the environment. Statement that was explained by Crittenden et al., (2009) cheating culture is where the environment can tolerate, they reliance that by doing the fraud, they can get what they want, and there is a perception that every person do the fraud in order to get success. Habits that mentioned before can be said that there was an awareness from the environment, but there is no assertive action and an assumption by the environment that this was a normal thing.

"Fraud happens because there is harmed side, so if he/she was not linked in the fraud, they certainly feel this thing is a fraud and if linked in the fraud, they certainly feel they do it right."

Putri as the informant said that the linkages will bring influence in the meaning of fraud, because if somebody was linked to the fraud, they lost their consciousness by doing fraud after they had done the fraud. Therefore, the status in cheating was one of the things that encouraged the existence of fraud habit culture. Status in fraud was related to the leader's habit who has unethical behavior (Crittenden, et al., 2009). While in this case, if a student saw fraud environment and resulted linkages between students, it caused the existence of fraud that influenced by other people who did the fraud.

"In my opinion, academic fraud itself is a truly social life, I am actually afraid of cheating. But in another side if I did not want to give my answer, it led to social judgment. I do not want that happens to me."

In the research that have been done by Morris \& Kilian, (2007) on the accounting students showed that there was academic fraud, it was supported by some reasons, so the researchers found a solution to the prevention by supervising academic environment with applying the culture to make an assertive action toward non ethical acts. The faculty party, Khomarul Alkarimah, S.E., M.M. as the Administrative manager in Ubaya stated that she had prevented this fraud by improving the total of supervisors which consisted of 3 people, lecturer, lecturer assistant, and faculty administrative party in order to minimize a chance, and there was a punishment socially which was reprimanding the perpetrators in front of their friends.

Lastly, fraud is a culture that has been happening for generations and had been done since kids by every fraud perpetrator, so there is no awareness that academic fraud such as cheating in the exam is a normal thing in the environment. Retrieving on the some previous research that linking between culture and corruption whether in private institution or public institution which showed the significant result, as the previous research that had done by Yeganeh, (2914) that culture in doing fraud was based on this Hofstede theory on 1980 significantly influenced toward corruption case. Therefore, the importance of supervising also reducing the fraud culture like this can affect the quality of ethical education in the future. 
Researcher identified the motivations that were owned by the accounting students in Universitas Brawijaya and University of Surabaya by considering fraud diamond theory. Along with its research, the researcher found new factor which fitted with research findings explained by informants which was ambition. Ambition had motivated the appearance of fraud factors such as pressure, opportunities, rationalization, and capability. The researcher assumed the ambition became main role of the appearance of fraud diamond theory elements. Along the statement given by Judge \& Kammeyer-Mueller, (2012) stated that ambition is a condition to reach the goals or plans to get an achievement. As the explanation above, researcher explain the link between ambition and fraud diamond theory in researcher's finding.

Grade is aimed to know the quality in every person, so there is a competition in getting high grade. Competition can become good and bad impact, as a research done by Wang et al., (2015) that desire to have good score is a pride, study abroad, or to be a leader are in the fourth place about the reasons why students do frauds. In this research, researcher also found that students did the fraud in order to get the best result.

"The society assertion is always keep asking a result, because result is more appreciated than the process. Sometimes, that mindset gives heart pressure in me. So I'd rather getting the best result though."

Generally, students assume that high score will affect to the work-life that will be reaching in the future. So the importance of getting perfect score become dreams for every students. Along with the statement stated by the informant that the importance of getting high score will affect to her job.

"I'm thinking about my future, 'where will I work' makes me feel that I have to get perfect score. Nowadays the requirement to get a good job is increasing, so I need to get best score."

The ambition was used to reflect the struggle for positions and wealth and it did not show the effort for general welfare and social-emotional acceptance (Judge \& Kammeyer-Mueller, 2012). In this case, the linkages between ambitions with academic fraud done by the informant showed that there was no effort to reach something, so the informant did unethical acts.

"I feel I want to get perfect score. Sometimes after I studied in a day before examination, I often forgot about the detail what I have studied yesterday because of nerves. So I decided, it is better to ask friend while exam going than getting bad score."

The assumption that accounting students must have high grade was the reason in every kind of frauds, therefore Subagyo, (2012) felt to help accounting students in reducing the pressure of getting good score is the most important by giving the understanding and material about the importance of having knowledge rather than good score. As this main thing that showed the linkages between ambition and fraud diamond theory.

Opportunity chance arise because there was a weakness in supervising system in the institution which caused people had chance to do frauds. This thing was used by the fraud perpetrators, based on this research to accounting students showed that there were opportunity have used for getting success. 
"I would never give my answer if the exam's supervisor is tight, it risks myself. So if my friend asked me, I just keep my mouth shut. But if the exam's supervisor is chill, I will give my answer only to my bestfriend."

"Been in the exam once without supervisor and we were free to do wherever we wanted, but it was the same as we took andvantage of the situation. We were in the same class doing the fraud together, by cheating together. We saw online books from Google which it did not allowed."

"Supervisor often gets bored if they supervising us, so they often talking to themselves of playing cellphone and the most comfortable if they read newspaper. So we have chances to ask or giving the answer to our friends.

"The hardest part is essay exam, I need to switch my questions paper with my friend. Because questions paper will never be submitted again, question paper must be taken home. That is applied in every course."

In this case, weak supervising system was the reason of academic fraud in the students. It was not only the supervisor who gave chance to the fraud perpetrators, there was also another factor in this opportunity which was rule application (Sagoro, 2013). There was also the result on the fraud perpetrators as those statements above.

"The rule about cutting all the courses off in one semester is exist, indeed, but I have never seen directly it applies to me or my friends. So all this time I feel secure with that."

"I ever felt the rule about that fraud in me, but it was not cutting the courses off, but I felt my score was being reduced if I was caught in doing fraud."

"I don't want to be as same as my friend who have been cut all the courses off in one semester yesterday just because he had been caught cheating, we are as students should understand about the chance as well as adjusting the available condition."

"I have seen my friend who had been given sanction by the faculty, all of his courses had been cut off in one semester. After that incidents, I was afraid of cheating, but the incidents was long time ago, so now I'm brave to do cheating."

Sagoro, (2013) stated that students and institutions have committed to prevent academic fraud, but the lectures gave chance and never give more attention, of course it made students took advantage of the opportunity that had been given. The less-discipline application of rule made there was no deterrent effect for the students, therefore students can feel secure if they did the fraud.

In this case, ambition has influenced fraud perpetrators by arising an idea to find opportunity in some times to get what they want. So, the presence of opportunity in academic fraud by the students gave the bad beginning that can trained students to find other opportunities to get an advantage. Opportunity had been proved by Andon et al., (2015) in their research had proved that a professional accountant in Australia got chance deception can trigger in making a decisions, decision in a deception. Therefore, the importance to identify an opportunity in every fraud, though in the low level of fraud.

Pressure can give a motivation in doing fraud. As explained Winrow, (2016) based on the operational management report, the main factor that made students do the fraud is the presence of the pressure to get success, such as a desire to be a worker, pressure from their parents, and getting the graduations. 
"Getting score in here (FEB, Ubaya) is so hard, so whatever it takes, we should deceive the supervisor so we can get good scores. Moreover if we failed in a course and we need to retake the course again, it is not nice though."

"The requirement from parents probably make him cheating, it's normal because he's afraid of failure."

"I often overwhelmed in doing exam, so it's better if I ask my friend, unless I will get bad score because I didn't answer the question."

Grade has big impact for the students because grade was the reflection from their success in the study, so they more concerned about the grade rather than the knowledge. Some informants also admitted that score were becoming fear which arose the pressure, this thing often became a reason by fraud perpetrators.

"I'm afraid if my score is bad and I need to retake my course in the next semester, besides, there is no shot term semester here, so I have to pay for the next more semesters, paying per semester isn't cheap and that makes burden for me."

"Score is the most frightening thing for me, so if I didn't know the answer in the exam, I would ask to my friend directly, I don't want to get bad score just because I didn't fill my answer."

Widyashanti, (2016) said that the element from the pressure is because the presence of trend, stress, or become a trigger for fraud perpetrators in doing the fraud. From that statement, it was stated clearly that stress can really influence the fraud. The underlying stress of the fraud perpetrator in doing fraud was affected by perpetrator's ambition. Along with the ambition owned by the perpetrators arise the research that mentioned that accountant was the important step in understanding individual behavior in fraud behavior. So at the time of education, accountant was required to understand an ethical value in the profession. Pressure which became a reason for fraud perpetrators was the thing to watch out for and was given the direction in order to reduce the fraud act on the accounting students.

Rationalization is an attitude which allows an individual does the fraud or the ability of someone in making a fraud becomes rational. Element in this fraud triangle had been stated by the informant as the fraud perpetrator.

"If I do not want to be an intermediary, my friends might be won't to talk to me.

So I often help my friend who needs my another friend by giving the same questions paper."

"I have never been in cheating before, but giving a cheat is a must, because I have ever been in the same position with them which means I cannot answer the question then my friend did not want to give his answer to me. I felt so mad, for that, I don't wanna do the same thing as my friend did."

"When in Introduction of Accounting course I had no courage to ask to my friend, but my friends gave the answer through the cellphone, this thing made me need to open my phone in order to see the answer from my friends. I felt sorry for my friends who cannot answer the questions, so if I could, I also spreading the answer as well."

Rationalization is the way to reduce the feeling of guilty in doing fraud. Less of guilty feeling that was owned by individual can raise the confidence toward his act, this thing because of the absence of sanctions by the social environment toward fraud perpetrators. 
"There was a guilty feeling when I'm in the elementry school, but now, as long as I don't be caught by the supervisor because of cheating, I don't have any guilty feeling."

"My guilty feeling is kind of like I need to ask permission to the students who has the answer, they allow it or not if I duplicated his idea. If my friend said it's okay, my guilty feeling is gone anyway."

"It is not the guilty feeling that I feel, because I will do it with the smooth process. What do I do if in the end I regret with what I've done."

"I have no guilty feeling, unless if I got bad score from cheating or cheating using the illegal small notes, I will regret this later."

"I'm sure if I cheat or be cheated, my friends will not report me to the supervisor because they are also students, so it can be sure that they understand. Then if I rarely reprimanded because of cheating so I'm going to be chill, because the rule of reprimanded is for the first call, the punishment has not been applied."

With ambition, the perpetrator had prepared a reason which assumed to be rational, so this fraud was assumed to be a normal. (J.L.Agud, 2914) stated that fraud had trended to study more in order to show off, because they assumed that this thing will influence life in the future. Therefore, the presence of statement explained by informants, that rationalization which was the fraud perpetrators' reasons were definitely revealed by the fraud perpetrators. Besides that, the absence of guilty feeling inside of the perpetrator made they did it arbitrarily in doing fraud with preparing some reasons that will be said, if they were caught.

The ability element stated by Wolfe \& Hermanson, (2004), is a characteristic and the private ability which plays the main role in the fraud that is really happening with three other unsure. This factor considered the position, intellectual capacity, feel of confident, and the ability to force and persuade. With the ability, the perpetrator can be easily did the fraud and had low risk level to be caught by doing fraud. This was proved by some accounting students who had the ability in fraud act will be very easy to do the fraud in the next day.

"If I give my answer to them, I look at my seat first, if my seat is in front of the watchman, I would never turn my face to my friends. In other hand, if I sat in the middle or next to the wall, I will give my answer to my friends and dropped my question paper together with my friend's paper so it pretended to be switched."

"I have never forced my friend to not to report me, but every student will understand, they will not report. But if someone reported, we would never make a friend with him/her."

"When I studied last night before examination day, I memorize theories that suppose to arise later, then in the class, I ask my friends who brave to open the books in the page bla bla bla so I spared from the cheating evidence."

"When I saw friend who brave enough to open the phone during the exam I was just quiet and will never report them, but I'm afraid to open my phone during the examination, I'd rather directly ask to my friend who opens the phone. I'm sure that the answer is convincing because they find it on the Google."

The ability owned by a student also can be influenced by the high ego and high confidence because they felt what they did were impossible to be detected, or someone believed that he/she can finish problems easily if they were caught (Wolfe \& Hermanson, 2004). So at this time, the ability was the dominant thing in 
influencing students to do the fraud such as their skills in convincing their friends to do the fraud together.

"On the difficult course usually I don't do cheating, but if my friends work togeher during the individual exam, I think it is okay to do. If I did not follow them, I will lost.

"Because we are in the same class that have made 'the circle of devil' (study group in every course to spread the answer to other groups which are not in their skill of course) I think I feel secure enough if I do the fraud, because impossible to report, if it so, they are all also caught."

"I'm sure, if I cheated or give my answer to my friends, they won't report me to the supervisor because they are all students so they must be understood. If I rarely reprimanded because of cheating, I'm going to be chill. In the rule, to be caught in cheating is only be reprimanded, the punishment itself has not been applied yet. Probably I'm going to dodge away from supervisor's stare, with applying 'thinking face' on me, so the supervisor did not know if I were talking to my friends."

This element had the equation with chance, but ambition and ability were the cause of chance, the ambition that underlined the perpetrators in finding ways by their ability to find that chance and when someone found a chance to do the fraud, they must had intelligence in understanding the situation and can exploit the weakness of control to get big advantages (Wolfe \& Hermanson, 2004). From this research, we can concluded that the motivation of academic fraud done by the students arise the ambition attitude that had been underlined fraud perpetrators so they had the linkages with fraud diamond theory, which is ability, chance, rationalization, and pressure. Ambition was someone desire in order to reach a target by justifying various ways although the way that was used was unethical behavior. With ambition, perpetrators will find the way in order to achieve goals and rewards. Statements that were stated by the informants were clearly that accounting students had tendency to do the fraud in order to get more advantages, by having motivations that came from different ambition in every student. Therefore, ambition as the motivation factor which underlined the academic fraud can be reduced by increasing the supervising more than usual.

\section{CONCLUSION}

Based on the analysis data and the result of discussion from this research, researcher can conclude that the result of this research are compatible with the research question, that are about the understanding of academic student by accounting students in undergraduate degree and found the motivation of doing fraud from perpetrators. The understanding of fraud academic by accounting students is the negative act that has considered as a normal act on their society, it is because of there is the encourages accompanied by intent in break the rules with rely on the laxity of exam control system. Not only break the rules, the understanding of academic fraud found that this act is already be a culture on this environment, so it makes this kind of fraud it's not to worry about. The motivation of accounting student who do the academic fraud when the appearance of ambition is underlie the fraud academic act, with the result that the ambition has linked to the fraud diamond theory, which contain of pressure, 
pportunity, rationalization, and capability. In this research, every single informant has indicate in doing fraud because they all have the high ambition to reach their goals. The limitation of this research is researcher only get small sampling then population. So it is better for next researcher has more informant to interviewed and for the object, they have to warn about the risks of cheating behavior then they have to improveing their rules to made the fraudulent are afraid of doing fraud.

\section{REFERENCES}

Andon, P., Free, C., \& Scard, B. (2015). Pathways to accountant fraud: Australian evidence and analysis. Accounting Research Journal, 28(1).

Crittenden, V. L., Hanna, R. C., \& Robert A. Peterson. (2009). The cheating culture: A global societal phenomenon. Business Horizons, 52(4).

Faucher, D., \& Caves, S. (2009). Academic dishonesty: Innovative cheating techniques and the detection and prevention of them. Teaching and Learning in Nursing, 4(2), 37-41.

J.L.Agud. (2914). Fraud and Plagiarisim in School and Career. Revista Clínica Española, 214(7).

Judge, \& Kammeyer-Mueller. (2012). On the value of aiming high: The causes and consequences of ambition. Journal of Applied Psychology, 97(4).

Kartikasari, R. N., Irianto, G., \& Prihatiningtias, Y. W. (2017). Penerapan Skeptisme Profesional Auditor Internal Pemerintah Dalam Mendeteksi Kecurangan Di Sektor Publik (Studi Pada Auditor Di Bpkp Perwakilan Provinsi Jawa Timur). Jurnal Akuntanso Akutual, 4(2).

King, C. G., Guyette, R. W., \& Piotrowski, C. (2009). Online Exams and Cheating: An Empirical Analysis of Business Students' Views. Journal of Educators Online.

Mavisakalyan, A., \& Meinecke, J. (2016). The labor market return to academic fraud. European Economic Review, 82, 212-230.

Minerva. (1986). Report of the committee on academic fraud the University of Chicago. 347-358. https://doi.org/https:// doi.org/10.1007/BF01096616

Moleong, L. (2015). Metode Penelitian Kualitatif Edisi Revisi. Remaja Rosdakarya.

Morris, D. E., \& Kilian, C. M. (2007). Do Accounting Students Cheat? A Study Examining Undergraduate Accounting Students' Honesty and Perceptions of Dishonest Behavior. SSRN.

Nursalam, N., Bani, S., \& Muniroh, M. (2013). Bentuk Kecurangan Akademik (Academic Cheating) Mahasiswa Pgmi Fakultas Tarbiyah Dan Keguruan Uin Alauddin Makassar. Jurnal Ilmu Tarbiyah.

Sagoro, E. M. (2013). Pensinergian mahasiswa, dosen, dan lembaga dalam pencegahan kecurangan akademik mahasiswa akuntansi. Jurnal Pendidikan Akuntansi Indonesia, 11(2).

Subagyo, M. (2012). Cheating Behavior Of Accounting Students: Evidence From State University Of Yogyakarta. Jurnal Universitas Jogjakarta.

Teixeira, A. A. C., \& Rocha, M. F. (2010). Cheating by economics and business undergraduate students: an exploratory international assessment. Higher Education, 663-701.

Wang, J., Tong, Y., Ling, M., Zhang, A., Hao, L., \& Li, X. (2015). Analysis on Test Cheating and its Solutions Based on Extenics and Information Technology. 
Procedia Computer Science, 55, 1009-1014.

Widyashanti, N. P. G. (2016). Factors affecting financial fraud of indonesian construction companies using fraud diamond perspective. Jurnal Ilmiah Mahasiswa FEB, 4(1).

Winrow, B. (2016). Do perceptions of the utility of ethics affect academic cheating? Journal of Accounting Education, 37, 1-12.

Wolfe, D., \& Hermanson, D. (2004). Fraud Diamond: Considering the Four Elements of Fraud. CPA Journal.

Yeganeh, H. (2914). Culture and corruption: A concurrent application of Hofstede's, Schwartz's and Inglehart's frameworks. International Journal of Development Issues, 13(1).

Yin, R. (2011). How to Start a Research Study. In: Qualitative Research from Start to Finish. Guilford publications. 